\title{
MODERN LITERARY EXILE THE ONES WHO LEAVE: NABOKOV, BRODSKY, ACIMAN
}

\author{
Kleitia VASO (Pomeranian University in Słupsk) \\ ORCID: 0000-0001-6215-4046
}

In the essay "The Condition We Call Exile," Joseph Brodsky, referring to the $20^{\text {th }}$ century, states that "displacement and misplacement are this century's commonplace." Political and religious issues constitute the primary reasons for the expulsions and subsequent exiles of Vladimir Nabokov (1899-1977), Joseph Brodsky (1940-1996) and André Aciman (1951), the principal figures analyzed in this study. The various works of the three authors who lived, in the cases of Nabokov and Brodsky, and continue to live - Aciman - in a permanent state of exile, provide the ideal framework for the analysis of this condition, its ever-accompanying nostalgia, and one's inseverable tie to the native realm. Brodsky and Nabokov who, for the majority of their lives, were deprived of the possibility of returning home, incline toward a less direct but, for that very reason, more subversively powerful expression of their sense of displacement and love for their common city of origin, St. Petersburg. Aciman, their successor in terms of the topic's centrality to his work, holds a more contemporary attitude to exile. While openly expressive of his nostalgia in a way that the other two resist, the emotion in Aciman acquires a more theoretical nature. Perhaps, as a result of his return visit to Alexandria, his native city, Aciman gains a clarity that Nabokov and Brodsky lack, while losing a certain depth of feeling in the process - he gains clarity at the expense of intensity. Yet, in order to illuminate the condition of exile during the previous and current century, specifically as it is detailed in the work of these three authors, the latter's numerous similarities and scarcer differences in their approaches to exile must be delineated.

The lives of Nabokov and Brodsky were profoundly affected by communism. The rise of communism in Russia caused the escape of Nabokov's aristocratic family from St. Petersburg. The author initially lived in Berlin and Paris, moving to the United States in the late 1930s. Although he spent several decades in America, Nabokov died

\footnotetext{
${ }^{1}$ Joseph Brodsky, On Grief and Reason (New York: Farrar, Straus \& Giroux, 1995), 23.
} 
in his native European continent, in Switzerland, a trajectory discussed in detail in Nina L. Krushcheva's Imagining Nabokov: Russia between Art and Politics. Constant migration and movement characterized the author's life and, as a result of strictness and rejection of individual freedom characterizing communism, he was unable to revisit his homeland and St. Petersburg, the city of his privileged childhood. In The Gift, the work John Burt Foster describes as "Nabokov's Russian émigré masterpiece"2 and the author's last novel written in Russian, Nabokov evokes his sense of displacement in Berlin through the experiences and responses of his protagonist, Fyodor GodunovCherdyntsev. In Nabokov's Art of Memory and European Modernism, Foster refers to The Gift as one of Nabokov's "fictive autobiographies"3 and claims that the Russian author's "preface to The Gift identifies this character as a partial avatar of himself in the 1920s, soon after his graduation from Cambridge. ${ }^{.4}$ Contrarian by nature, Nabokov dismisses any obvious connections. He insists that, although he "had been living in Berlin since 1922, thus synchronously with the young man of the book," the reader should not be misguided by this fact; "nor [Nabokov's] sharing some of his interests, such as literature and lepidoptera, should make one say 'aha' and identify the designer with the design." Memory, the author insists that Fyodor and the author are not interchangeable beings. Yet, the protagonist's unease in The Gift undoubtedly corresponds to author's situation and emotions while in exile, a conclusion corroborated by Foster's claim that "eventually, in a metafictional mirroring of his character's doctrine, Nabokov would acknowledge that a number of Fyodor's experiences were his own." ${ }^{.6}$ Foster continues by citing several supporting instances, i.e. corresponding episodes in The Gift and Nabokov's autobiography, Speak, Memory, thus verifying Brodsky's bold statement that "what goes into writing a book — be it a novel, a philosophical treatise, a collection of poems, a biography, or a thriller — is, ultimately, a man's only life."7

Like Nabokov, though lacking his privileged and wealthy childhood, Brodsky left St. Petersburg when threatened and, subsequently, arrested by the Communist Party. He escaped from St. Petersburg and the Baltic, a part of the world for which one "had indeed to be an eel to escape" ${ }^{\text {"8 }}$ at that particular time, in 1972. Again, like Nabokov, he never returned home and spent most of his life in America, teaching and writing. Yet, despite the conscious decision to live in the United States, the author took yearly trips to Venice, "Petersburg's extension into a better history, not to mention latitude.""

Lacking the professed nonchalance of Nabokov, embittered by his country's politics, Brodsky resists the open display of nostalgia for his native city, a resistance that only serves to further emphasize his yearning in the depictions of Venice, the substitute home, seemingly similar but endowed with "Western ideals," standing as "the antipode of the Soviet Union.",

2 John Burt Foster, Nabokov's Art of Memory and European Modernism (New Jersey: Princeton University Press, 1993), xiii.

${ }^{3}$ Ibid, 130

${ }^{4}$ Ibid, 147 .

${ }^{5}$ Vladimir Nabokov, The Gift, transl. Michael Scammell (New York: Vintage, 1991), xi.

${ }^{6}$ Foster, Nabokov's Art of Memory, 26.

${ }^{7}$ Brodsky, On Grief and Reason, 97.

${ }^{8}$ Joseph Brodsky, Watermark (New York: Farrar, Straus \& Giroux, 1992), 6.

${ }^{9}$ Ibid, 38.

${ }^{10}$ Sanna Turoma, Brodsky Abroad: Empire, Tourism, Nostalgia (Madison: University of Wisconsin Press, 2010), 166. 
Aciman also left Alexandria, his native city, for political reasons. In 1956, when the author was a teenager, the Egyptian government began expelling foreign minorities from the country, including "many Jews: everyone had assets, businesses and properties seized by the state." 11 As wealthy Jewish Alexandrians, Aciman's family suffered the same fate. While they escaped the enforced expulsion that year, they eventually moved to Europe nine years later, in 1965. The author's family first settled in Italy, a stay which also included numerous trips to France. Afterward, in 1968, they relocated to the United States, specifically New York, Aciman's permanent residence.

Unlike Nabokov and Brodsky, Aciman returned to see Alexandria, a visit detailed in False Papers. This return enables his examination of exile from various perspectives. His anticipated nostalgia, the unsatisfactory return, the city's apparition in unexpected places represent only a few of the facets addressed by Aciman. His completion of the circular journey rids him of the illusions/delusions that Brodsky and Nabokov retain in their nostalgic state, enabling him to analyze the condition as someone who has undergone all of its different stages.

Regardless of their differences, a common thread - the constant interference of the past in their present lives - links the experience of all three exiled authors. In a definition that emphasizes the violence of the condition, Edward Said defines exile as "the unhealable rift forced between a human being and a native place, between the self and its true home," a rift whose "essential sadness can never be surmounted."12 $\mathrm{He}$ continues by describing it as "a discontinuous state of being," one in which "exiles are cut off from their roots, their land, their past." condition of exile denotes a forceful detachment from the native place and an aggressive interruption in the normal flow of life. Expatriation uproots the individual from an original place and removes one to new soil that requires changes in the already formed constitution and character. This "unhealable rift" severs life into multiple, seemingly unconnected parts, a fragmentation which, in turn, creates a disjointed existence that comprises the simultaneous influences of both the old and adopted homes, yet remains suspended between the two. The original place loses its status as home at the moment of exile, the latter a term which, according to Brodsky, "covers, at best, the very moment of departure, of expulsion."14 Yet, while the exile's native place can never fully represent home again, this place affects the perception and appreciation, or lack thereof, of every subsequent "home." The head of the writer in exile, notes Brodsky in "The Condition We Call Exile," remains "like the false prophets of Dante's Inferno, forever turned backward." 15 The explanation for this fixed backward glance lies in the fundamental role that the original home, specifically the environment of the formative years, occupies in the development of the individual, his tastes and modes of perception. This double life, writes Katarzyna Jerzak, constitutes exile's "distinct chronotope. This chronotope is characterized by a doubled perception of reality: the exile functions in a new world, but his inner compass is invariably pointed back

\footnotetext{
${ }^{11}$ André Aciman, False Papers (New York: Farrar, Straus \& Giroux, 2000), 6.

${ }^{12}$ Edward W. Said, Reflections on Exile and Other Essays (Cambridge: Harvard University Press, 2000), 173

${ }^{13}$ Ibid, 177.

${ }^{14}$ Brodsky, On Grief, 31.

${ }^{15}$ Ibid, 27.
} 
home. ${ }^{" 16}$ Memory, therefore, assumes the dominant function in the life of an exiled author. While the sense of home remains permanently out of their reach, memory, in its involuntary form - i.e. the Proustian memory, one spontaneously activated by the senses, as famously illustrated in the "Overture" to À la recherche du temps perdu transports the exile home. Through voluntary memory, specifically the methodical revisiting and retrieval of the past, the author attempts to retain an intact self. In their works, Nabokov, Brodsky, and Aciman emphasize their attachment to their respective native cities and analyze the inevitable damage that the separation from the place of origin inflicts on both self and life.

According to all three authors' experience, once an individual is separated from their native city, the term home irretrievably loses its meaning. After revisiting Alexandria, a journey during which he "had hoped finally to let go of this city," Aciman clarifies that, though always present in his thoughts, the city "is no longer home for [him]."17 Experiences of other places, author's physical distance from Alexandria and his life in New York, have robbed the city of its role as home. For Brodsky, the permanent loss of St. Petersburg is solidified by his actual inability to return. Even when a return becomes feasible, he refuses to do so. In Brodsky Abroad: Empire, Tourism, Nostalgia, Sanna Turoma's analysis of Brodsky's antipathy for the "the fast travel of the 'round trip' in the jet-plane era [that] denies the passage of time provided by traditional transportation (train, ship), and introduces the "phenomenon of speed',"'18 suggests Brodsky's inclination toward a slower, more idealistic world order, one in which an exile does not return to his home city just because they can. Brodsky, aware of the possible dangers, does not fulfill his desire, but subverts it instead. Similarly, Nabokov was unable to return to the communist Russia. Although he is more openly expressive than Brodsky, confessing that "anything on any continent resembling the St. Petersburg countryside and my heart melts" and admitting to the occasional temptation to "see again my former surroundings," he knows that this wish can only be fulfilled by "revisiting them with a false passport, under an assumed name." ${ }^{, 19}$ Although "it could be done," the author admits that he does "not think [he] shall ever do it." ${ }^{20} \mathrm{He}$ accepts that the loss is irrevocable and untreatable by a mere physical return.

The irreversible loss extends to all present and future residences as well. Once the native realm loses its privileged position, the title becomes invalid and can no longer be claimed by any other place. The most significant consequence of exile is precisely the loss of faith in home as a concept. In "Shadow Cities," Aciman defines an exile as "not just someone who has lost his home," but as "someone who can't find another, who can't think of another." ${ }^{21}$ According to Aciman, substitution becomes impossible because "some no longer even know what home means." ${ }^{22}$ The finality of this loss echoes Baudelaire's insightful diagnosis of exiles as beings that have "perdu ce qui ne

${ }^{16}$ Katarzyna Jerzak, "Life in Translation: Exile in the Autobiographical Works of Kazimierz Brandys and Andrzej Bobkowski," in Exile as the Home of the $20^{\text {th }}$ Century, ed. John Neubauer (Berlin: de Gruyter, forthcoming), 1.

${ }^{17}$ Aciman, False Papers, 21.

${ }^{18}$ Sanna Turoma, Brodsky Abroad: Empire, Tourism, Nostalgia (Madison: University of Wisconsin Press, 2010), 54.

${ }^{19}$ Vladimir Nabokov, Speak, Memory: An Autobiography Revisited (New York: Vintage, 1989), 250.

${ }^{20}$ Ibid.

${ }^{21}$ Aciman, False Papers, 39.

${ }^{22}$ Ibid. 
se retrouve / jamais, jamais!"23 ("lost what can never / be found again!",24) The author's emphasis on the word never in "The Swan" indicates the eternal inability to belong anywhere, one incited by the original loss. The latter begins with the physical and extends to the metaphysical. In the case of the three authors, two reasons emerge as the fundamental obstacles inhibiting an adaptation to a new place: the authors' own rejection of the new dwelling as home, and the unbidden and uncontrollable interference of the past upon the present.

For all three writers, the adopted place fails to transform into a new home. In the cases of Brodsky and Aciman, the United States, which become their permanent abode, fail to acquire the title and defining features of home. Because he uses a fictional disguise, Fyodor, Nabokov is at once less direct and more open about his intense dislike of Berlin and his total detachment from this temporary residence. Less extreme, Aciman is able to find a measure of comfort in a corner of New York. Yet, the corner offers him this sensation of familiarity precisely because it makes him forget where he is. In "Shadow Cities," Aciman claims that Straus Park, his favorite spot in the city, affords him a sense of belonging because, "depending on where I sat, or on which corner I moved within the park, I could be in any of four or five countries and never for a second be in the one I couldn't avoid hearing, seeing and smelling." 25 For Aciman, New York can recreate the feeling of being a home because it represents an ideal point of departure for his constant imaginings of other places. This city, he adds, "is my home precisely because it is a place from which I can begin to be elsewhere - an analogue city, a surrogate city, a shadow city." ${ }^{26}$ New York, therefore, assumes the shaky role of home precisely because it offers no false delusions of being one. Instead, the amalgamation of different cultures and architectural styles enables Aciman's imaginary transportation to other, more beloved places. The shadow presence of these other cities offers the author the temporary illusion of being home.

Similarly, Brodsky's life in the United States includes all the necessary components for success, most importantly, an illustrious career as professor and writer. Yet, in Watermark, his literary hymn to St. Petersburg via Venice, Brodsky implies that, for him, the United States represent a transitory place: in Brodsky's eyes the United States remain "a kind of Purgatorio," 27 the rest stop between heaven and hell. St. Petersburg, on the other hand, is anything but neutral, encompassing both paradise and inferno. In The Future of Nostalgia, Svetlana Boym writes that, "according to Yuri Lotman, the city was perceived simultaneously as a paradise and hell, as a utopia of the ideal city and the nefarious masquerade of the Russian Antichrist." ${ }^{28}$ In its guise as Leningrad, the city represents the hell from which Brodsky had to escape, while its heavenly aspect is assumed by Venice, his "version of Paradise," St. Petersburg with "a better history." 29 One cannot live neither in heaven, nor hell and, thus, the United States emerge as an in-between place, a waiting room, or a bridge connecting the place that must be escaped and the desired destination.

${ }^{23}$ Charles Baudelaire, Les Fleurs du Mal et Oeuvres Choises, transl. Wallace Fowlie (New York: Dover, 1992), 76.

${ }^{24}$ Ibid, 77.

${ }^{25}$ Aciman, False Papers, 43.

${ }^{26}$ Ibid, 46.

${ }^{27}$ Brodsky, Watermark, 19.

${ }^{28}$ Svetlana Boym, The Future of Nostalgia (New York: Basic books, 2001), 398.

${ }^{29}$ Brodsky, Watermark, 38. 
In a similar manner to Brodsky and Aciman, Fyodor, Nabokov's partial double, fails to feel at home in Berlin. Walking through the city's streets, Fyodor resents their feigned and aggressive familiarity. These streets, Fyodor thinks, "that had already long since insinuated themselves into his acquaintance," are not satisfied with this detached familiarity but, "expected affection." $" 30$ The city's forceful demand for an affection that the young author feels unable to give, repulses Fyodor. Berlin remains foreign, a truth which emerges in two contrasting poems that the aspiring young poet writes about it and St. Petersburg. The poem about St. Petersburg is not discussed at length; the author merely suggests that its content is positive judging from the response of Fyodor's mother, who "liked so much" the poems "on Russia." 31 While the first lines of the poem about Russia emphasize the country's natural beauty, "the yellow birches in the blue sky..."32 the poem about Berlin evokes a place in which "things... are in a sorry state; / even the moon is much too rough / though it is rumored to come straight / from Hamburg where they make the stuff. ${ }^{, 33}$ The first line openly expresses Fyodor's dislike of the city, with the subsequent one suggesting that even natural elements like the moon feel unfamiliar and artificial in the alien city. The poem about Russia conveys a sensation of happiness and peace, whereas the poem about Berlin suggests a state of detached despair. Fyodor's perspective of his home implies what Hana Píchová deems "an idealization of Russia, or what Said terms 'a fetish of exile", 34 in her discussion of Mary, Nabokov's first novel. This fetishistic attachment stands at the root of Fyodor's extreme detachment from his new surroundings, a disconnect that becomes palpable when he visits an old apartment in Berlin that he, his mother and sister previously occupied. In a half-hearted attempt at inducing nostalgia, "Fyodor and his mother went to have a look at the apartment house where the three of them had lived for two years," but, despite the familiarity with this space, "there was nothing their hearts could recognize." 35 The lack of imprint on Fyodor's memory is caused by what Jerzak names the "disturbing unreality of the exile's surroundings." ${ }^{36}$ Something unreal cannot leave an actual mark. The previous owners recognize no aspects of themselves in this specific place; the people and the environment exchange nothing with each other, and the place remains a neutral living space that cannot be transformed into a home.

Fyodor's poem about Berlin indicates another aspect of the exile, especially visible in Nabokov's and Brodsky's writing, which inhibits the establishment of a home in the West. Fyodor's suggestion that in Germany even the moon is manufactured, conveys the author's view that the West possesses a predominantly artificial nature. While Aciman feels somewhat adjusted to the West, perhaps because of his family's continued ties to Europe, Nabokov and Brodsky suggest that the West seems more desirable from a distance. In a moment of intense hatred for Berlin, Fyodor identifies the source of his intense dislike of the city and its inhabitants: their unnatural "love of fences, rows, mediocrity; for the cult of the office; for the fact that if you listen to [their] inner voice (or to any conversation on the street) you will inevitably hear figures, money... for the visibility of cleanliness - the gleam of saucepan bottoms in the kitchen and the

\footnotetext{
${ }^{30}$ Nabokov, The Gift, 53.

${ }^{31}$ Ibid, 93 .

${ }^{32}$ Ibid.

${ }^{33}$ Ibid, 94

${ }^{34}$ Haná Píchová, The Art of Memory in Exile: Vladimir Nabokov \& Milan Kundera (Illinois: Southern Illinois University Press, 2002), 22-23.

${ }^{35}$ Nabokov, The Gift, 90.

${ }^{36}$ Jerzak, "Life in Translation," 8.
} 
barbaric filth of the bathrooms. ${ }^{, 37}$ The common thread that links all of the various accusations is Fyodor's utter disdain for superficiality. The West - Berlin, specifically - depicted here seems to favour materialism over spiritual life and surfaces rather than content; because of this emphasis, a writer, predisposed by nature and/or trade to introspection, is especially unsuited to the West. And yet, the route from the East here Eastern Europe, primarily - to the West represents the dominant path for the massive migration of the twentieth century. In "The Condition We Call Exile," Brodsky notes that the West, as a professed democracy, remains the only logical destination for authors who had to evade the totalitarian regimes of Eastern Europe: "from a tyranny one can be exiled only to democracy." ${ }^{38}$ However, precisely because of its assumed role as the ideal, the West can only disappoint. Brodsky states that, during communism, in a natural response to the suffocating atmosphere, the Russians "with our instinct for individualism fostered at every instance by our collectivist society, with our hatred toward any form of affiliation, be that with a party, a block association, or, at that time, a family, were more American than Americans themselves. ${ }^{, 39}$ While the United States, an "industrially advanced society with the latest word on individual liberty on its lips, ${ }^{, 40}$ theoretically embodies all the advantages and principles of freedom, Brodsky insists that the Russians like him "were the real Westerners, perhaps the only ones." 41 $\mathrm{He}$ calls his circle of friends 'the real Westerners' because, living in an oppressive environment, they really clung to and believed in the ideals of the West. Indeed, in The Future of Nostalgia Boym explains that "while in the Soviet Union, Brodsky was considered to be one of the most 'Western oriented writers, possessed by 'abroadsickness'." ${ }^{42}$ However, she continues, "the poet never stopped longing, and in fact persisted in his alienation when he arrived in the admired West." ${ }^{\text {"43 }}$ As "imagination counterbalances and at times outweighs reality, ${ }^{, 44}$ Brodsky clarifies in his own words, the dreamed-of West acquires a more powerful reality than the real one which, in turn, promises more on the surface than it is able to deliver. This incongruity between promise and delivery, resulting in disappointment, makes it impossible for the authors to feel completely at home in the West.

Another reason for the authors' discomfort in their new surroundings is their willful resistance to them. In "Reflections on Exile," Said claims that "the exile jealously insists on his or her right to refuse to belong." ${ }^{45}$ For exiles, the new place can never represent a home because they carry their old cities and countries within. Alongside the original home's constant presence, exiles willfully revert their thoughts to the past. In "Shadow Cities," Aciman claims that New York acquires importance once it enables the author to become transported to other cities, Rome, Paris, or London, all of which ultimately represent Alexandria. "Straus Park, this crossroad of the world, this capital of memory, this place where the four fountains of the world and the four quarters within me meet one another is not Paris, is not Rome, could not be

\footnotetext{
${ }^{37}$ Nabokov, The Gift, 81.

${ }^{38}$ Brodsky, On Grief, 24.

${ }^{39} \mathrm{Ibid}, 14$.

${ }^{40}$ Ibid, 24

${ }^{41}$ Ibid, 14.

${ }^{42}$ Boym, The Future of Nostalgia, 865.

${ }^{43}$ Ibid, 866.

${ }^{44}$ Brodsky, On Grief, 13.

${ }^{45}$ Said, Reflections on Exile, 182.
} 
London or Amsterdam, Frankfurt or New York. It is, of course, Alexandria." $" 46$

Therefore, in coming to Straus Park the author actively tries to recapture his past. He visits the park to do "what all exiles do on impulse, which is to look for their homeland abroad, to bridge the things here to things there, to rewrite the present so as not to write off the past." ${ }^{, 47}$ Indeed, the bridge, as Píchová points out, is an ideal metaphor for the exile who must "struggle to maintain a tenuous balance as if at a precarious height; the émigré finds himself or herself on a kind of unstable, rickety bridge between two shores, where the new, unknown territory has to be appropriated and familiarized while the old, known territory becomes the realm of the imaginary."

Aciman attempts to reverse this order by willfully damaging the present in order to keep the past intact. The price, however, for forcefully preserving the past becomes the permanent forfeiting of a new home.

Like Aciman, Brodsky refuses to settle or, at least, accept his settling. He purposefully divides his life into two different parts: the seemingly permanent existence in America and his yearly sojourns to Venice. Venice is Brodsky's closest approximation to heaven, although he never feels a part of it. Despite the frequency of his visits, he accepts that he "never could convincingly claim, even to [himself], that [he] had acquired any local traits." 49 Indeed, Brodsky's feeling of nonbelonging emerges most visibly in his fantasies of becoming a local. He dreams of

wasting his afternoons in the empty office of some local solicitor or pharmacist, eyeing his secretary as she brought in coffee from a bar nearby, chatting idly about the prices of motorboats [...], exchanging malicious remarks about the new German battalions or the ubiquitous Japanese peeping through their cameras. ${ }^{50}$

The imagined scenarios betray his status as an eternal outsider and the fervent but impossible desire of attaining a certain amount of stability in this city. However, despite his suggestion that his love for the city is unrequited, it is Brodsky who determines his fate, seals his non-belonging, by deliberately refusing to settle in either one place. While he refers to Venice as the dream part of his life, to which he "kept returning myself, rather than the other way around," either to abandon his dreams of belonging or to attempt to actually settle there. His persistent attachment and subsequent visits to Venice result in the erosion "of what constituted my reality," his life in America, and yet, the author does not mind this inevitable erosion. Indeed, he notes that "reality suffered more" than the dream; he deliberately strips America of the chance to become a home. ${ }^{53}$ Yet, by the same token, he simultaneously prevents the dream, Venice, from acquiring real features. To start a new life, "one ought to be able to wrap up the first one," 54 an action that the author is unwilling to take. Instead, he hovers between two lives, a "transient in either realm," unable to settle in either world. Deciding whether to dwell in the present or past

\footnotetext{
${ }^{46}$ Aciman, False Papers, 49.

${ }^{47}$ Ibid, 38 .

${ }^{48}$ Píchová, The Art of Memory in Exile, 2.

${ }^{49}$ Brodsky, Watermark, 122.

${ }^{50}$ Ibid, 63.

${ }^{51} \mathrm{Ibid}, 121$.

${ }^{52}$ Ibid, 64.

${ }^{53}$ Ibid, 121-122.

${ }^{54}$ Ibid, 64.

${ }^{55} \mathrm{Ibid}, 122$.
} 
involves a sacrifice of either one. In The Art of Memory in Exile: Vladimir Nabokov \& Milan Kundera, Píchová, quoting Henri Bergson, suggests that a complete return to the more comforting past requires the sacrificing of the present: "According to Henri Bergson, 'To call up the past in the form of an image, we must be able to withdraw ourselves from the action of the moment, we must have the power to value the useless, we must have the will to dream'. ${ }^{, 56}$ One must choose between either dream or reality and, if one does not, the result is a state of perpetual suspension.

The superimposition of St. Petersburg on Venice becomes clear in the overlapping descriptions of Venice in Watermark and St. Petersburg in "A Guide to a Renamed City." Although Brodsky eludes the explicit connection between the two, his preference for visiting Venice in winter, "at the wrong time of the year," when the surrounding water seems alternately "blue [and] at times, gray or brown," for St. Petersburg. Both cities are characterized by the overwhelming presence of water, its reflective surface. In Venice, water forces the inhabitants and tourists to devote time and effort to their appearance because of the "natural surplus of mirrors here, the main one being the very water." 58 Brodsky employs a similar turn of phrase in his description of St. Petersburg, where the "ubiquitous presence of water" reflects "every second by thousands of square feet of running silver amalgam, as if the city were constantly filmed by its river." ${ }^{, 59}$ Another element that confirms the interchangeable identity of the two cities in Brodsky's texts is their similar winter light. A defining trait of St. Petersburg, writes Brodsky, is the unchangeable "northern light, pale and diffused, one in which both memory and eye operate with unusual sharpness." ${ }^{60}$ The Venetian version of this same pale light represents, for the author, one of the most beautiful effects of winter in the Italian city. On several occasions, he praises "the winter light in this city," which possesses the "extraordinary property of enhancing your eye's power of resolution to the point of microscopic precision." ${ }^{61}$ However, the explicit parallels between the two cities are scarce. The first time Brodsky sees Venice, it is in a few melancholy pictures which suggested "what I wanted them to suggest: winter, the true time of the year." ${ }^{22}$ Winter represents the true time of the year for one born and raised in the wintry Baltic. Indeed, the pictures of Venice, because of "the texture and melancholy conveyed" represented a state "so familiar to me in my own hometown," one that "made these pictures more comprehensible, more real." "63 The past and St. Petersburg, its locus, influence both present and future. Yet, Brodsky prefers to imply rather than render explicit, silence representing a way of preserving the past, keeping it to oneself. That, at least, is what Boym suggests when she cites Marco Polo's silence regarding Venice, his home city, in Italo Calvino's Invisible Cities: “The great Venetian traveler Marco Polo never speaks of Venice directly because he is always speaking about Venice: 'Memory images, once they are fixed in words are erased. Perhaps I am afraid of losing Venice at once, if I speak of it'."64 The reticence in Brodsky suggests a similar concern and aim, namely preservation through silence.

\footnotetext{
${ }^{56}$ Píchová, The Art of Memory in Exile, 20.

${ }^{57}$ Brodsky, Watermark, 21.

${ }^{58}$ Ibid, 26.

${ }^{59}$ Joseph Brodsky, Less than One (New York: Farrar, Straus \& Giroux, 1986), 77.

${ }^{60}$ Ibid, 89.

${ }^{61}$ Brodsky, Watermark, 78.

${ }^{62}$ Brodsky, On Grief, 15.

${ }^{63}$ Ibid.

${ }^{64}$ Boym, The Future of Nostalgia, 902.
} 
The past influences Fyodor's world in The Gift as well. Through his protagonist, Nabokov shows that the impossibility of a place's transformation into a new home greatly depends on the expatriate's perspective. During a ride in a tramcar, a man accidentally bumps into Fyodor. Believing the passenger to be German, the occurrence of "this trivial thing turned his irritation into a kind of pure fury, so that, staring fixedly at the sitter, reading his features, he instantly concentrated on him all his sinful hatred (for this poor, pitiful, expiring nation) and knew precisely why he hated him: for that low forehead, for those pale eyes; for Vollmilch and Extrastark." ${ }^{65}$ The rage, intensely and undeservedly directed at the other passenger, illustrates Fyodor's overall unhappiness and irritation with his life in Berlin. As a result, every one of his gestures and interactions with the locals is marred by this rage and unhappiness. While Fyodor continues to enumerate the German nation's shortcomings and ridiculous features, the man who incited such hatred begins to read a Russian newspaper. Suddenly, Fyodor relaxes and thinks: "That's wonderful [...] How clever, how gracefully sly and how essentially good life is!" 66 The discovery that the man is Russian, rather than German, completely transforms Fyodor's mood and perspective on life. The man's face, one which initially possesses every stereotypical German trait despised by Fyodor, now reflects "a compatriotic softness." 67 The newspaper reader does nothing right or wrong in this episode; his nature and character are purely determined by Fyodor's perspective. The episode clarifies the source of Fyodor's discomfort in his new life in Berlin, namely the attachment to his previous home, one that skews his perspective. In fact, Fyodor later realizes that Berlin's failure to turn into a home stems, primarily, from Fyodor's own lack of love for the city. As he leaves yet another apartment, Fyodor claims to feel only a certain "subtle sorrow of parting with an unloved abode." ${ }^{\circ}$ The place means little to him, not because of a particular shortcoming, but because he refused to bring the apartment "to life with [my] breath." He does not hold any affection for the apartment; indeed he "hardly noticed" it. This place, therefore, not only means little to Fyodor in the present, but already constitutes a "dead inventory," which "will not be resurrected later in one's memory." 69 Fyodor's refusal to bestow any affection on his new surroundings eliminates any chance of Berlin becoming a home.

The authors' persistent attachment to the past is undoubtedly connected to the inherent need of safeguarding oneself. In "Estrangement as a Lifestyle," Svetlana Boym states that an émigré protects "a portable home away from home" because it "preserves an imprint of his or her cultural motherland.", The protection of memory, therefore, is directly linked to the preservation of a collective and personal identity. For instance, while thinking of his father, an enigmatic figure of the greatest importance for the young author, Fyodor feels a sudden sadness caused by the realization of memory's limitations. He resolves that he will do the utmost to preserve his lepidopterist father's "captures, his observations, the sound of his voice in scientific words." despite Fyodor's willful preservation of these memories, he realizes, sorrowfully, that

\footnotetext{
${ }^{65}$ Nabokov, The Gift, 81.

${ }^{66}$ Ibid, 82.

${ }^{67}$ Ibid.

${ }^{68} \mathrm{Ibid}, 144$.

${ }^{69}$ Ibid.

${ }^{70}$ Susan Rubin Suleiman, ed., Exile and Creativity: Signposts, Travelers, Outsiders, Backward Glances (Durham and London: Duke University Press, 1998), 244.

${ }^{71}$ Nabokov, The Gift, 112.
} 
"that is still so little.,"72 Fyodor's sadness arises from his knowledge that memory is fickle and that the eventual forgetting of beloved people and places is inevitable. In Nabokov's Art of Memory and European Modernism, John Burt Foster highlights an episode in the novel in which mother and son can remember the missing father "only in the form of fleeting allusions; its full public expression becomes highly problematic." $" 73$

Like Fyodor, Brodsky and Aciman realize that the person in exile must expend considerable amounts of energy to maintain strong ties to the past which is gradually erased by the demands of the present. In "Pensione Eolo," Aciman receives news of a job offer in Italy, an opportunity that could mean the fulfillment of his wish for an eventual return to Europe. This exciting prospect, however, fails to fill the author with the happiness he expects, and, instead of rejoicing, he becomes increasingly concerned with the departure from New York and the anticipation of a growing chasm between him the city once he moves away from it. This unexpected sense of disappointment reminds Aciman of his transition from Europe to America. Frightened by the thought of growing distant from Europe, once in America, Aciman continued to buy "French and Italian magazines so as not to let go of Europe, knowing all along, however, that [he'd] unavoidably lose touch and that despite [his] promises of holding on to the old, the new invariably had ways of demoting old things."74 Thus, Aciman's primary purpose becomes the recovery of the slippery past, the very process of remembering. In The Future of Nostalgia, Boym explains that "Aciman called such adulteration of memory 'arbitrage' or rememoration," a phenomenon in which "the memory of a place, and not the place itself, becomes a subject of remembrance, revealing that one's personal stakes arc in several places at once."75 The author places less importance on the recall of specific events than on "the beauty of remembering, realizing that just because we look back doesn't mean we love the things we look back on.,"76 The process of looking back constitutes an attempt to preserve the self rather than indicating an actual wish to return to the previous life. Although this process of recovery may fail to yield the desired result, the striving to recall the past and rebuild the self suffices. Even though "you may never find yourself," Aciman notes, "you remember looking for yourself," a process that "can be reassuring, comforting." "F7 For Aciman, this restorative process takes place in Straus Park, the point in which the author's old world and his new life converge. This place, he suggests, seems to be created precisely for "retrospection, for finding oneself, for finding the center of things." 78

Brodsky expresses a similar concern regarding the inability of the human mind to retain the past. Through the acts of remembering and writing, he aims at the crystallization of past events. In "Less than One," the author recalls his childhood because he has "never done so before, because [he] want[s] some of those things to stay - at least on paper."79 The author's effort to reproduce the past on paper proves difficult, mainly because of the past's gradual erasure from the inconsistent human memory. Despite his wholehearted dedication to the task, the "effort to reproduce the tail in all its spiral splendor is still doomed, for evolution wasn't for nothing. The

\footnotetext{
${ }^{72}$ Ibid.

${ }^{73}$ Foster, Nabokov's Art of Memory, 69.

${ }^{74}$ Aciman, False Papers, 135.

${ }^{75}$ Boym, The Future of Nostalgia, 903.

${ }^{77}$ Aciman, False Papers, 44.

${ }^{77}$ Ibid, 44.

${ }^{78}$ Ibid, 41.

${ }^{79}$ Brodsky, Less than One, 7.
} 
perspective of years straightens things to the point of complete obliteration." 80 The inevitable passage of years displaces the old and replaces it with new events and memories. Despite this displacement, the author relentlessly attempts to recapture the past and fix it on paper, as he is well aware of the innumerable links that exist between the self and the former life that shaped it. Features, inclinations and dislikes are all products of the formative environment. Even in Venice, St. Petersburg's double, the author looks for traces of his past in the reflection of water, an element that he believes records and stores each aspect of the city and its inhabitants. In the gray waters of Venice which, in turn, recall the reflective river Neva in St. Petersburg, Brodsky looks for images of his previous self. "The reason [he is] engaged in straining [the water]," writes the author in Watermark, "is that it contains reflections, among them [his] own." 81

In addition to the conscious pursuit of the past, the authors' disconnect from their new environment is also caused by the unbidden interference of their previous surroundings, activated by the uncontrollable mechanism of involuntary memory. In Nabokov's Art of Memory and European Modernism, John Burt Foster draws attention to Proust's influence on Nabokov, specifically in The Gift. Addressing Fyodor physical discomfort in his new setting, Foster explains that "this series of encounters with the unaccustomed, which then becomes automatized, might recall Russian formalist doctrines of defamiliarization, but the evocation of Proust is more pointed and precise. As with the magic-lantern scene, the fiction-reading, or the darkened bedroom of "Mademoiselle O," Nabokov's point of departure is again the overture to the Recherche." ${ }^{, 2}$ During the first day in his new lodgings, Fyodor resents being assaulted by a "degrading boredom, the recurrent refusal to accept the vile yoke of recurrent new quarters, the impossibility of living face-to-face with totally strange objects, the inevitable insomnia on that daybed!" 83 He hears everything with a "Russian ear," in which his landlady's German name, Klara Stoboy sounds "with a sentimental firmness as 'Klara is with thee (s toboy)'.", ${ }^{\prime \prime}$ Indeed, Fyodor's attachment to St. Petersburg, the city of his childhood, stems from the fact that the environment to which he was first exposed shapes the way he sees everything afterwards. The body acts as a reservoir, a repository of views, perceptions and memories. As such, childhood acquires the greatest importance, because his "eyes are, in the long run, made of the same stuff as the grayness, the clarity, the dampness of those sites." ${ }^{\prime \prime 5}$ The city and the individual become one; they absorb one other. Katarzyna Jerzak credits Henri Bergson with the idea that "we perceive reality through what we have seen, what we have experienced before." 86 Because Fyodor's eyes are shaped by the specific sights of St. Petersburg, they cannot help but reject new and alien sights. This fundamental mismatch renders exile a physically uncomfortable condition. The senses can eventually adjust to a new environment, but never completely.

Aciman bypasses an explicit discussion of the formative role of the native environment on a person's senses. Yet the effects of growing up in Alexandria, a port city, dictate the author's constant and permanent attraction to the beach and to water in

\footnotetext{
${ }^{80}$ Ibid, 30.

${ }^{81}$ Brodsky, Watermark, 21.

${ }^{82}$ Foster, Nabokov's Art of Memory, 149.

${ }^{83}$ Nabokov, The Gift, 7.

${ }^{84}$ Ibid.

${ }^{85}$ Nabokov, The Gift, 25.

${ }^{86}$ Jerzak, "Life in Translation," 11.
} 
general. On his way to France, as he gets a glimpse of the Adriatic Sea, Aciman reaches the conclusion that, "for an Alexandrian, used to having the beach within sight all day long," seeing the sea again "was like meeting a close sibling two years after a quarrel:

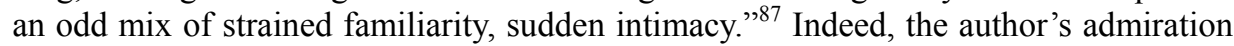
of the sea is not purely aesthetic. The sea is a constituent part of him: "beach as a way of life, beach at the hand's reach, beach in the blood. Just as in Alexandria." ${ }^{88}$ External elements permeate the physical body and, as a result, the author constantly searches for places, experiences, sensations that resemble and echo the formative environment. Aciman emphasizes this natural fusion of a person and place in a recent interview in Vanity Fair, in which he discusses Find Me, the sequel to Call Me by Your Name. For those familiar with Aciman's oeuvre prior to his novel-turned-film, it is clear that the childhood and early adulthood detailed in False Papers and Out of Egypt inform the atmosphere and setting of Call Me by Your Name. Discussing his previous experiences in Paris and Rome - Italy being the setting of the hugely popular novel - Aciman writes:

I know that when I write about Rome, where I lived, and about Paris, where I also lived, in many ways it's kind of touching base again, that metaphor. It's like looking at the cobblestones and seeing that, yeah, there's a part of me that's entrenched in those cobblestones. ${ }^{89}$

In Watermark, Brodsky also addresses the idea of recognizing oneself in the external elements. As he arrives in Venice, the author smells "freezing seaweed," which awakens in him a "feeling of utter happiness," 90 sparked by the recognition of "the elements of your composition being free." ${ }^{.91}$ At this particular moment of contentment, the smell exists, at once, outside and inside the author's body. In a similar manner, the eye belongs to both body and the external object on which it focuses; it "identifies itself not with the body it belongs to but with the object of its attention." external views are the dominant force that affect the eye and shape one's constitution. Because the environment so powerfully influences the individual, one cannot immediately and definitively separate oneself from a significant place. Departure from the city, continues Brodsky, "is not the body leaving the city but the city abandoning the pupil." ${ }^{93}$ The city absorbed by the eye and body, however, does not disappear; instead, affecting views and vistas are "banished to the crevices and crevasses of the brain." $" 94$ It is thus that Brodsky explains the mechanics of the aforementioned episode in which he recognizes himself in the external elements. This experience is enabled by the body's ability to absorb and retain exterior sights and smells, a quality which turns it into a carrier of space. Inversely, while Boym also emphasizes this fusion of body and place, she views it as a form of "self-effacement," in which the body is diffused through the environment rather than the latter contained within it. "The smell of

${ }^{87}$ Aciman, False Papers, 24.

${ }^{88}$ Ibid.

${ }^{89}$ Keziah Weir, "Find Me Author André Aciman Talks Eternal Youth, a Hollywood Sequel, and That Peach Scene," Vanity Fair, October 31, 2019, https://www.vanityfair.com/style/2019/ 10/find-me-andre-aciman-new-book-interview, Accessed December 7, 2019.

${ }^{90}$ Brodsky, Watermark, 5.

${ }^{91}$ Ibid, 7.

${ }_{92}$ Ibid, 110.

${ }^{93}$ Ibid.

${ }^{94}$ Ibid. 
seaweed vodorosli, wonderfully onomatopoeic in Russian gives him a sense of utter happiness. The poet's body is not dismembered but is made porous, open to smells, sights and sensations, set free." ${ }^{, 95}$ The body becomes fluid rather than rigid, water-like. The reflective water of Venice "equals time and provides beauty with its double. Because we are "part water, we serve beauty in the same fashion," 96 Brodsky writes. Like water, people reflect the outside environment and retain specific parts of it, particularly the elements of the formative environment which lend the same molecular makeup to one's tastes and perceptions.

The triggering by these simultaneously external and internal elements awakens memory - Proust's involuntary memory — and the past, unbidden this time, aggressively affects the present. Brodsky writes that the exile's continuous looking back is activated by a "retrospective machinery [that] is constantly in motion in an exiled writer, nearly always unbeknownst to him." $" 97$ The machine, of course, is memory which, at times, operates without the permission of the exile. In these moments, the exiled author is not engaged in an active pursuit of the past; the past, rather, without his knowledge, suddenly appears and overtakes him. The smell of freezing seaweed renders Brodsky happy precisely because this specific smell is connected to his youth in St. Petersburg. Always resistant to obvious connections, Brodsky denies that the "attraction to that smell should have been attributed to a childhood spent by the Baltic." 98 This denial is unconvincing, however, because in "A Guide to a Renamed City," the author emphasizes the very same smell in his description of St. Petersburg. In St. Petersburg, writes Brodsky, "the seaweed-smelling head wind from the sea has cured here many hearts oversaturated with lies, despair, and powerlessness." 99 The curative effect of the Russian seaweed-smelling wind explains the author's happiness in Venice. In fact, Brodsky becomes so utterly engrossed by the images the smell evokes that he prefers to remain in his fantasy rather than confirm his present location, Venice. As he ponders the lines of a poem he translated in Russia, the author loses track of his location and, though he could turn around and see "the stazione in all its rectangular splendor of neon and urbanity, the block letters saying VENEZIA," ${ }^{100}$ he does not.

In The Gift, Fyodor addresses the existence of moments in which the past attacks the present in his poems. In a poem composed in an instant of pure inspiration, the young author expresses his gratitude towards his homeland "for [her] remotest / most cruel mist," 101 which both possesses and ignores him. Interestingly, Boym employs similar terms in her discussion on Brodsky's relationship to Venice, dubbing it a story of unrequited love. "This is an ideal love affair, unreciprocal, unconsumated and perfectly satisfying. The lover accepts the indifference of the beloved and is grateful for her sheer existence and for the possibility on occasion to reflect himself in her many mirrors," 102 she writes. Fyodor is a less sophisticated and worldly lover than Brodsky. In the fictional character's case, the attacks of the past appear slightly ominous, destructive. His present interactions with people in Berlin, which he describes as "talks

\footnotetext{
${ }^{95}$ Boym, The Future of Nostalgia, 904.

${ }^{96}$ Brodsky, Watermark, 134.

${ }^{97}$ Brodsky, On Grief, 29.

${ }^{98}$ Brodsky, Watermark, 6.

${ }^{99}$ Brodsky, Less than One, 89.

${ }^{100}$ Brodsky, Watermark, 8 .

${ }^{101}$ Nabokov, The Gift, 56.

102 Boym, The Future of Nostalgia, 904.
} 
between somnambules," become violently interrupted by memories of the past, without knowing if "it's my demency that rambles / or [her] own melody that grows." 103 This poem perfectly captures the unbidden and overwhelming invasion of memories and their damaging consequence on the character's present life. In exile, writes Jerzak, the past "overtakes the present, swallows it up, spills over." 104 The intermingling of these two realities, she continues, causes the exile to "live in two places at once: in one as a body, in the other as phantom." 105 Because of the past's constant reappearance, Fyodor can only exist as a ghost in his real life in Berlin. He likens the assaults of the past to "a fatal illness," epileptic fits which occur "at any hour, in any place," frequently during Fyodor's walks through the streets of Berlin. In one such moment, as Fyodor steps "across an unpaved section," 107 memories from his family's summer house transport him to that particular place. Then and there he realizes that "it was in his feet that he had the feeling of Russia, that he could touch and recognize all of her with his soles, as a blind man feels with his palms." 108 Through his sensory awareness of Russia, Fyodor escapes the streets of Berlin and re-enters the world of his childhood, walking "toward the still invisible house," 109 complete with the presence of his father and mother. In his case, the attacks of involuntary memory acquire a pathological nature; Fyodor is unable to live in Berlin because his senses frequently transport him to the other world, the world of his childhood.

In Aciman, the instances in which the environment activates the senses, triggering the author's transportation to a past place, are numerous. In a particularly Proustian passage, the uncomfortable sensation of a pair of wool trousers sets in motion the retrospective machine. During a walk through New York, the discomfort created by the combination of wool and heat reminds Aciman of his father's trousers, later altered for the young author so that he could wear them in the family's first adoptive city of Rome. This discomfort stimulates Aciman's memory and he feels a "flush of almost sexual pleasure." 110 The pleasure, the author explains, stems from the memory of his days in Rome, when the heat that emanated from the wool would propel him to search for a fountain "where I could entertain the illusion that I was one step closer to the beach in Egypt and - if the illusion lasted - to our summer house, to my friends and relatives, and to an entire world that I longed to recover: the city I had known as a child, the smells, the heat, the cast of light." 111 The sudden sensation of pleasure bridges the gap dividing childhood and present, and the past materializes once more. This physical tie to his past in Italy is palpable in Call Me By Your Name, in the ambience of the entire novel and, afterward, film, and, more specifically, in the location of the story. In a New Yorker article, Aciman explains the reason for the "vagueness" of the location, which he simply designates as "somewhere in Northern Italy." "Such vagueness is deliberate," he explains, as "the point of a paradise is that it could exist anywhere but that, once you

${ }^{103}$ Nabokov, The Gift, 56.

${ }^{104}$ Katarzyna Jerzak, "Exile as Life after Death in the Writings of Henryk Grynberg and Norman Manea," in The Writer Uprooted: Contemporary Jewish Exile Literature, ed. Alvin H. Rosenfeld (Bloomington: Indiana University Press, 2008), 77.

${ }^{105}$ Ibid.

${ }^{106}$ Nabokov, The Gift, 80.

${ }^{107}$ Ibid, 63.

${ }^{108}$ Ibid.

${ }^{109}$ Ibid, 79.

${ }^{110}$ Aciman, False Papers, 156.

${ }^{111}$ Ibid. 
reach the place, it brims with details so precise in their intensity that you never forget them." "He circumvents any explicit links to his past but, through the juxtaposition of the aforementioned episode in False Papers and the coming-of-age story depicted in the film, it is obvious that the latter could only be set in a place that mirrors the actual background of the author's own coming-of-age.

Whether voluntary or unbidden, the authors' imaginary returns to their cities of origin testify to their affection for these specific places. Indeed, the authors can only use the term love when referring to their native cities. During his actual return to Alexandria, Aciman realizes that he attempts to reconnect with the city, the one that he carries with him everywhere, in a detached, perfunctory manner. As he walks determinedly but hurriedly to the places that hold a particular importance for him, Aciman concludes that "everything about [him] is trying to discourage contact with a city that is, after all, the only one [he] think[s] [he] love[s]." ${ }^{113}$ The love that connects the author to Alexandria becomes a diluted form of the same emotion in Aciman's relationship with New York. In "Shadow Cities," Aciman praises Straus Park for its ability to conjure images of the author's favorite cities, all of which ultimately recall different facets of Alexandria. The author's introduction to this particular park with its strange ability to recall distant places, while erasing the features of the city which physically surrounds the author, indicates the time "when I started to love, if 'love' is the word for it, New York." 114 He almost loves New York because the city possesses the ability to disappear, to temporarily transform itself into other places, to contain pieces of elsewhere.

In a similar way, Brodsky, while bestowing upon America the title of reality, refrains from expressing any affection for his new country. Although his relationship with St. Petersburg is troubled, Brodsky's strong emotional connection to it becomes apparent in the city's description in "Less than One," as well as in his insistence on revisiting Venice yearly, for seventeen years. Although Brodsky feels somewhat alienated in Venice and refers to his days there as the dream part of his fragmented life, Venice, more so than America where he spends the major part of the year, approximates the notion of home primarily because of the author's adoration for the city. And, while he characterizes his existence in Venice as ghostly, Brodsky notes that " a case could be made for fidelity when one returns to the place of one's love, year after year, in the wrong season with no guarantee of being loved back."115 Although Boym cites him as referring to Venice as "a Penelope of a city," 116 it is he who is both the loyal Penelope and a somewhat failed Odysseus. She, on the other hand, is continuously ravished by countless tourists, an issue that repeatedly surfaces throughout the long essay. Sanna Turoma claims that "the phenomenology of tourism Brodsky writes in Watermark, discloses his continuous search for an authentic Venice, the intimate, the private, the nontouristic."117 This affection and dedication in establishing an intimate rapport with the city succeed in transforming the city into an approximate home. However, Brodsky's arrival in Venice during the wrong season, winter, betrays the author's search

${ }^{112}$ Lane, Anthony. “'Call Me By Your Name”: An Erotic Triumph,' The New Yorker, December 4, 2017 issue, https://www.newyorker.com/magazine/2017/12/04/call-me-by-your-namean-erotic-triumph, Accessed December 5, 2019.

${ }^{113}$ Aciman, False Papers, 10.

${ }^{114}$ Ibid, 43.

${ }^{115}$ Ibid, 123

${ }^{116}$ Boym, The Future of Nostalgia, 904.

117 Turoma, Brodsky Abroad, 226. 
for the real home, St. Petersburg. In "Less than One," he explicitly expresses his love for the city and bemoans St. Petersburg's change into Leningrad under the communist regime. In the conclusion of the essay, which is presented as a fairy tale, furthering the distance between the author and the city, Brodsky writes: "And there was the city. The most beautiful city on the face of the earth. With an immense gray river that hung over its distant bottom like the immense gray sky over that river."118 Although eternally separated from his native city and disappointed with its subjection to a cruel regime, the author deems St. Petersburg, both undisguised and in the guise of its reflection, Venice, as the most beautiful place in the world. St. Petersburg claims such a privileged position because, for the author, the city represents the first and, therefore, defining source of the author's notion of beauty.

Fyodor, who resents his new home, Berlin, more than Aciman and Brodsky do theirs, can only express affection for Russia. Towards the end of the novel, Nabokov's protagonist and foil provides a brief definition of himself. His internal self, notes the character, the "personal I," is the one that loves "words, colors, mental fireworks, Russia, chocolate and Zina." 119 Casually placed between a trivial love of chocolate and his actual lover, Zina, Fyodor's love of Russia is presented as one of the fundamental shaping forces of the character. In Speak, Memory, writing without a fictional guise, Nabokov is as unambiguous as Fyodor in his expression of affection for his native place. He describes St. Petersburg as a lost Paradise, so powerful in its beauty and offering such a "sense of security, of well-being, of summer warmth," that its "robust reality makes a ghost of the present." Strong Opinions, Nabokov cites love as the primary factor in the preservation of specific memories. He claims that "it is all a matter of love. The more you love a memory, the stronger and stranger it is. I think it's natural that I have a more passionate affection for my old memories, the memories of my childhood, than I have for later ones, so that Cambridge in England or Cambridge in New England is less vivid in my mind than some kind of nook in the park on our country estate in Russia." 121 The love of a place and time, suggests the author, ensures the recurrence and return of the past. In the case of exiled authors, love is only possible in relation to their native cities.

Despite its pain and irrevocable losses or, precisely because of them, exile serves as a creative machine. For many exiled authors, displacement becomes the only and, in some cases, the preferred mode of existence. As a modern prophet, Baudelaire already senses, in his metaphysical exile, the perverse satisfaction that one might derive from displacement. In the conclusion of "The Swan," the poet characterizes exiles as beings who "tettent la douleur comme une bonne louve,"122 ("suckle Grief as if she was a kind wolf" $"$ "123 thus suggesting that exiles not only depend on pain but derive nourishment from it, even, perhaps, perversely enjoying it. Indeed, once displaced from Russia, Brodsky deliberately furthers the damage by dividing his life between Italy and America, never settling in either place. Nabokov spent "20 years in America, and yet [he] never owned a home or had a really settled establishment there." ${ }^{, 124}$ In Imagining

\footnotetext{
${ }^{118}$ Brodsky, Less than One, 32.

${ }^{119}$ Nabokov, The Gift, 334.

${ }^{120}$ Nabokov, Speak, Memory, 77.

${ }^{121}$ Vladimir Nabokov, Strong Opinions (New York: Vintage, 1990), 12.

${ }^{122}$ Baudelaire, Les Fleurs, 76.

${ }^{123}$ Transl. Wallace Fowlie.

${ }^{124}$ Nabokov, Strong Opinions, 27.
} 
Nabokov, Nina L. Khrushcheva claims that Nabokov's penchant for living in hotels expresses a "bitter freedom, in which man, having lost paradise forever, is merely a guest on earth with no reason to accumulate heavy life baggage." ${ }^{.125}$ Aciman explains this state of perpetual instability as the only possible home for the exile. The exiled individual can only find a home, "the spiritual home, the capital," in the "traffic between places, and not the places themselves." 126 The only home, therefore, becomes the very condition of displacement. Indeed, Edward Said concludes his memoir, Out of Place, by defining the exilic condition as "a form of freedom."127 This sense of freedom emerges from the author's recognition that because of "so many dissonances in [his] life," he has renounced the search for a permanent home because he has "learned actually to prefer being not quite right and out of place." 128

Aciman perfectly illustrates this preference in the essay "In Search of Blue," in which he details an ideal trip to the Italian coast, one which disappoints him because of its very perfection. In a flawless room with an extraordinary view of the sea, a sight he has long searched for, the author feels unhappy because, "used to deferral and denial," "when confronted with plentitude, [he] caught myself wishing it had never existed." 129

He is unequipped to deal with perfection; instead, he prefers a "more diluted, more fragmented, oblique, obstructed" 130 kind of experience. His preference for something incomplete derives from the author's inclination to complete or analyze that which is fragmentary with his imagination, his thoughts. A complete experience, writes the author, leaves "nothing more to want. Nothing more to say." "131 As a writer, Aciman suggests, perfection, while capable of providing a momentary sense of happiness, is self-sufficient, requires nothing extraneous to it to complete it. For Nabokov and Brodsky, fulfillment is not a matter of choice. Realizing that once separated from their country, they can never wholly belong anywhere, the two Russian authors forcefully damage their lives, opting never to return. They exchange stability and a return they know will be disappointing for the ability to dream, imagine and write. They embody Witold Gombrowicz' statement that "not only émigré art but all art remains in the most intimate contact with decay, it is born of decadence, it is a transmutation of illness into health." "132 Indeed, judging by the works of Nabokov, Brodsky, and Aciman, one can conclude that the only compensation for the damaged life is literary output, its product.

\section{BIBLIOGRAPHY}

Aciman, André. False Papers. New York: Farrar, Straus \& Giroux, 2000.

Aciman, André. Out of Egypt. New York: Riverhead Books, 1996.

Baudelaire, Charles. Les Fleurs du Mal et Oeuvres Choises, ed. end transl. Wallace Fowlie. New York: Dover, 1992.

Boym, Svetlana. The Future of Nostalgia. New York: Basic books, 2001.

${ }^{125}$ Nina L. Khrushcheva, Imagining Nabokov: Russia between Art and Politics (New Haven \& London: Yale University Press, 2007), 51.

${ }^{126}$ Aciman, False Papers, 139.

${ }^{127}$ Edward W. Said, Out of Place (New York: Vintage-Random House, 2000), 295.

${ }^{128}$ Ibid.

${ }^{129}$ Aciman, False Papers, 27.

${ }^{130}$ Ibid.

${ }^{131}$ Ibid.

${ }^{132}$ Witold Gombrowicz, Diary, Volume One, ed. Jan Kott, transl. Lillian Vallee (Illinois: Northwestern University Press, 1988), 39. 
Brodsky, Joseph. Watermark. New York: Farrar, Straus \& Giroux, 1992.

Brodsky, Joseph. On Grief and Reason. New York: Farrar, Straus \& Giroux, 1995.

Brodsky, Joseph. Less than One. New York: Farrar, Straus \& Giroux, 1986.

Foster, John Burt. Nabokov's Art of Memory and European Modernism. New Jersey: Princeton University Press, 1993.

Gombrowicz, Witold. Diary, Volume One, ed. Jan Kott, transl. Lillian Vallee. Illinois: Northwestern UP, 1988.

Jerzak, Katarzyna. "Modern Exile and Perspective in Baudelaire's 'Le cygne' and in pittura metafisica," unpublished paper.

Jerzak, Katarzyna. "Exile as Life after Death in the Writings of Henryk Grynberg and Norman Manea." The Writer Uprooted: Contemporary Jewish Exile Literature, ed. Alvin H. Rosenfeld, 75-91. Bloomington: Indiana UP, 2008.

Jerzak, Katarzyna. "Life in Translation: Exile in the Autobiographical Works of Kazimierz Brandys and Andrzej Bobkowski." Exile as the Home of the $20^{\text {th }}$ Century, ed. John Neubauer. Berlin: de Gruyter, forthcoming.

Khrushcheva, Nina L. Imagining Nabokov: Russia between Art and Politics. New Haven \& London: Yale UP, 2007.

Lane, Anthony. '“Call Me By Your Name”: An Erotic Triumph.' The New Yorker. December 4, 2017 issue. https://www.newyorker.com/magazine/2017/12/04/call-me-by-your-name-anerotic-triumph. Accessed December 5, 2019.

Nabokov, Vladimir. The Gift, transl. Michael Scammell. New York: Vintage, 1991.

Nabokov, Vladimir. Speak, Memory: An Autobiography Revisited. New York: Vintage, 1989.

Nabokov, Vladimir. Strong Opinions. New York: Vintage, 1990.

Píchová, Haná. The Art of Memory in Exile: Vladimir Nabokov \& Milan Kundera. Illinois: Southern Illinois University Press, 2002.

Rubin Suleiman, Susan, ed. Exile and Creativity: Signposts, Travelers, Outsiders, Backward Glances. Durham and London: Duke U P, 1998.

Said, Edward W. Out of Place. New York: Vintage-Random House, 2000.

Said, Edward W. Reflections on Exile and Other Essays. Cambridge: Harvard UP, 2000.

Turoma, Sanna. Brodsky Abroad: Empire, Tourism, Nostalgia. Madison: University of Wisconsin Press, 2010.

Weir, Keziah. "Find Me Author André Aciman Talks Eternal Youth, a Hollywood Sequel, and That Peach Scene." Vanity Fair, October 31, 2019. https://www.vanityfair.com/style/ 2019/10/find-me-andre-aciman-new-book-interview. Accessed December 7, 2019.

\section{MODERN LITERARY EXILE THE ONES WHO LEAVE: NABOKOV, BRODSKY, ACIMAN}

Before the culture of constant travel and movement characterising the $21^{\text {st }}$ century, there was the exile of the $20^{\text {th }}$ century, a century defined, according to Joseph Brodsky, by "displacement and misplacement." The Russian author is one of the primary writers whose works are analysed in this paper, with the other two being Vladimir Nabokov and André Aciman. The lives and works of those three authors are connected by the common thread of exile, along with the symptoms of the condition: the unbreakable connection between individual and the native city, the regaining of the past through the process of remembering, the "attacks" of involuntary memory, the suspended life between past and present, and using art as the supplement of a fragmented life but also as its compensation. Brodsky and Nabokov, who never returned to their homelands, lean toward a less direct but, for that very reason, more powerful expression of their sense of displacement and love of their common city of origin, St. Petersburg. Aciman, the youngest and the only living one of the trio, holds a more contemporary attitude to exile. While openly expressive of his nostalgia in a way that the other two resist, the emotion in Aciman acquires a more theoretical nature. Because he eventually revisits Alexandria, his native city, Aciman gains a clarity that the other authors lack, one informed by the completion of the exilic cycle. The 
numerous commonalities and fewer differences of the three authors shed significant light on the condition that has become commonplace in the contemporary world.

KEY WORDS: exile, involuntary memory, native city, nostalgia, $20^{\text {th }}$ century

WSPÓLCZESNE LITERACKIE WYGNANIE. CI, KTÓRZY WYJECHALI: NABOKOW, BRODSKI, ACIMAN

Przed kulturą ciągłej podróży i ruchu charakteryzującą XXI wiek było wygnanie XX wieku definiowanego przez Josepha Brodskiego jako wiek ,wysiedlenia i zawieruszenia”. Ten rosyjski autor jest jednym $\mathrm{z}$ trzech, których dzieła zostały poddane analizie $\mathrm{w}$ tym artykule - pozostali to Władimir Nabokow i André Aciman. Życia i dzieła tychże autorów łączy nić wygnania i jego symptomy: nierozerwalna więź pomiędzy jednostką a miastem rodzinnym, odzyskiwanie przeszłości poprzez pamiętanie, „napady” wspomnień, stan zawieszenia pomiędzy przeszłością i teraźniejszością i używanie sztuki nie tylko jako formy zastąpienia, ale również jako kompensacji utraconego życia. Brodski i Nabokow, którzy nigdy nie wrócili do ojczyzny, opisują swoje poczucie wysiedlenia i miłość do swojego rodzinnego miasta, Petersburga, w sposób mniej dosadny, ale o wiele bardziej emocjonalny. Z kolei Aciman, najmłodszy z całej trójki, prezentuje o wiele bardziej współczesne podejście do wygnania. Chociaż mówi o swojej nostalgii w sposób bardziej otwarty niż Brodski i Nabokow, emocje przez niego wyrażane wydają się mieć naturę teoretyczną. Jako że Aciman wraca wreszcie do swojego miasta rodzinnego, Aleksandrii, daje mu to lepszy wgląd w zrozumienie wygnania i emocji, które ono wywołuje. Podobieństwo doświadczeń trzech autorów rzuca światło na doświadczenie, które stało się codziennością współczesnego świata.

SŁOWA KLUCZOWE: wygnanie, pamięć mimowolna, miasto rodzinne, nostalgia, XX wiek 